\title{
Organelle inheritance in plants
}

\author{
XAVIER REBOUD $† \&$ CLIFFORD ZEYL ${ }^{*}$ \\ Laboratoire d'Evolution et Systématique des Végétaux, Bâtiment 362, Université Paris Sud, 91405 Orsay CEDEX, France \\ and TDepartment of Biology, McGill University, 1205 Avenue Docteur Penfield, Montréal, Québec, Canada H3A $1 B 1$
}

\begin{abstract}
Most angiosperms are thought to share strict maternal inheritance of both plastids and mitochondria. Exceptions have been described and analysed, especially for plastids. However, the lack of phenotypic markers and the use of RFLPs on small samples may have biased the prevailing view of organelle inheritance by underestimating the occurrence of low-frequency paternal transmission of organelles. According to Muller's Ratchet, some recombination among organelle genomes is required, which would necessitate at least occasional biparental transmission. Uniparental inheritance can reduce the spread of selfish genetic elements and maintain good combinations of alleles. However, this does not explain why organelles transmitted by both parents have not invaded populations with uniparental inheritance. A link between outcrossing reproductive systems and the occurrence of biparental transmission suggests that plastids may play more of a genetic role in their inheritance than is usually assumed. Their prevailing non-Mendelian mode of inheritance thus remains to be convincingly explained.
\end{abstract}

Keywords: chloroplasts, intracellular conflict, non-Mendelian inheritance, organelle transmission, reproductive systems.

\section{Introduction}

Organelle inheritance in most plants is purely maternal, with just enough exceptions to produce a substantial body of literature on the topic. Our view of organelle inheritance patterns has changed in response to advances in research techniques. However, the predominance of uniparental organelle inheritance has yet to be convincingly explained.

In this paper, we summarize the impact of methodology on present knowledge of organelle inheritance. We then review known mechanisms of organelle inheritance and discuss evolutionary explanations of inheritance patterns which suggest new experimental approaches.

\section{Impact of methodology on present knowledge}

Interest in organelle inheritance was aroused only 10 years after the rediscovery of Mendel's laws (Correns, 1909). The study of organelle inheritance began with the use of phenotypic markers (the most popular of which remains chlorophyll deficiency) and has recently been extended by molecular and cytologi-

\footnotetext{
*Correspondence.
}

cal approaches. The advantages and disadvantages of these three approaches are summarized in Table 1 . Because the disadvantages of one technique can often be overcome by the use of another, recent studies often combine approaches. However, we think that technical limitations have influenced prevailing views of organelle inheritance in at least four ways.

1 The inheritance of mitochondria is an almost untouched topic and is still too often ignored. Only six cases in which mitochondrial inheritance is not strictly maternal have been discovered, two of these by the use of interspecific crosses (Table 2), in contrast to plastids for which more than 40 such cases have been described. This may reflect either inherent differences between these organelles or the lack of mitochondrial phenotypic markers.

2 Crop and ornamental plant species are overrepresented relative to wild species (see Table 3). This impedes attempts to understand the evolutionary reasons for inheritance patterns as changes in these patterns may be by-products of domestication, such as selection on reproductive systems (e.g. male sterility) or changes in plastome-genome interaction resulting from hybridization. This is particularly unfortunate as the DNA polymorphisms required by molecular techniques are probably more abundant in wild plants than in cultivated plants. 
Table 1 Advantages and disadvantages of three major approaches to the study of organelle inheritance in plants

\begin{tabular}{|c|c|c|}
\hline Method & Advantages & Disadvantages \\
\hline \multirow[t]{4}{*}{ Phenotypic markers } & Very large samples can be screened & Few markers exist \\
\hline & $\begin{array}{l}\text { Selective screening sometimes possible } \\
\text { (e.g. resistance to herbicides (Gasquez et }\end{array}$ & Restricted to plastids \\
\hline & $\begin{array}{l}\text { al., 1981) or to antibiotics (Medgyesy etl. } \\
\text { 1986)) }\end{array}$ & $\begin{array}{l}\text { Markers may not be neutral, affecting inferred } \\
\text { inheritance patterns }\end{array}$ \\
\hline & $\begin{array}{l}\text { Requires minimal equipment or materials } \\
\text { and thus accessible to most labs }\end{array}$ & $\begin{array}{l}\text { Spontaneous mutations, alteration in chimeral } \\
\text { shoots, and restitution of mutant plastids may } \\
\text { affect estimated transmission frequencies }\end{array}$ \\
\hline \multirow[t]{4}{*}{ Molecular techniques } & $\begin{array}{l}\text { Greatly increases number of potential } \\
\text { markers }\end{array}$ & $\begin{array}{l}\text { Expensive and laborious, thus restricting sample } \\
\text { sizes and possibly preventing detection of low } \\
\text { frequency paternal inheritance; also, biased }\end{array}$ \\
\hline & $\begin{array}{l}\text { Permits analysis of mitochondrial as well as } \\
\text { chloroplast inheritance }\end{array}$ & towards species of economic interest \\
\hline & $\begin{array}{l}\text { Origin of organelle DNA can be indisputably } \\
\text { determined, so alternative explanations for } \\
\text { apparent paternal transmission can be } \\
\text { eliminated }\end{array}$ & $\begin{array}{l}\text { Requires DNA polymorphism; where intraspecific } \\
\text { polymorphism is absent, interspecific crosses } \\
\text { are required and novel plastome-genome } \\
\text { interactions may induce atypical inheritance } \\
\text { (Sundberg \& Glimelius, 1991; Chiu \& Sears, } \\
\text { 1993) }\end{array}$ \\
\hline & & $\begin{array}{l}\text { RFLP techniques insensitive to minute amounts of } \\
\text { DNA, precluding analysis of heteroplasmy, which } \\
\text { requires PCR }\end{array}$ \\
\hline \multirow[t]{4}{*}{ Cytology } & Easily mastered & $\begin{array}{l}\text { Restricted to few individuals or genotypes, so may } \\
\text { be misleading when generalized }\end{array}$ \\
\hline & Applicable to a large range of species & \\
\hline & $\begin{array}{l}\text { Informative regarding mechanisms and } \\
\text { stages of organelle exclusion }\end{array}$ & $\begin{array}{l}\text { indicate their inclusion in the zygote, which is } \\
\text { usually the question of interest }\end{array}$ \\
\hline & Requires no markers & \\
\hline
\end{tabular}

Table 2 Species in which inheritance of mitochondria is not strictly maternal. In such species, plastid inheritance is also frequently not strictly maternal. References include methods of analysis (M;R), abbreviated as in Table 3 except for Brassica napus, in which maternal inheritance of the mitochondrial genome was inferred from the inheritance of a mitochondrial plasmid

\begin{tabular}{ll}
\hline Species & Reference \\
\hline Brassica napus & Erickson et al. $(1989)$ \\
Calocedrus decurrens & Neale et al. $(1991)$ \\
Hordeum vulgare $\times$ Secale cereale & Soliman et al. $(1987)$ \\
Petunia hybrida & Derepas $(1991)(\mathbf{M} ; \mathbf{R})$ \\
Pinus banksiana $\times$ contorta & Wagner et al. $(1991)(\mathrm{R})$ \\
Sequoia sempervirens & Neale et al. $(1989)(\mathrm{R})$ \\
\hline
\end{tabular}




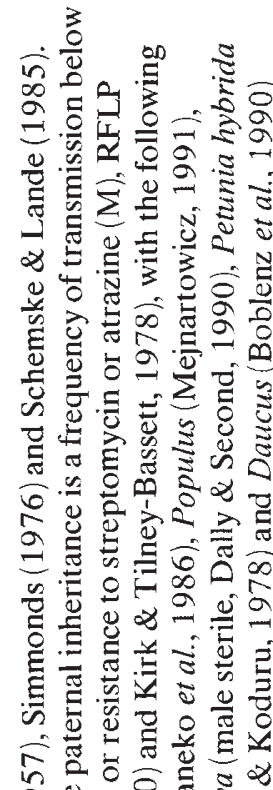

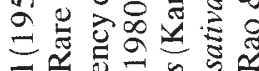

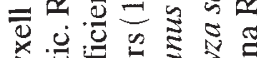

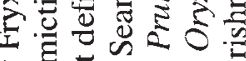

ते

एٓ

कo $\frac{0}{0}$ क人

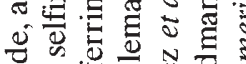

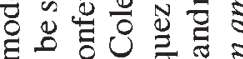

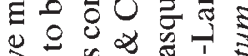

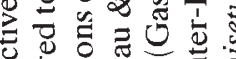

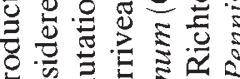

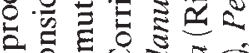

웡

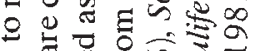

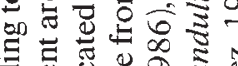

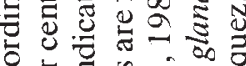

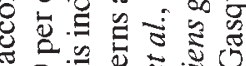

ช을

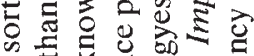

की

है

on 3

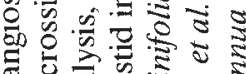

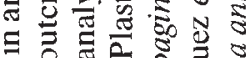

प

可 它

य

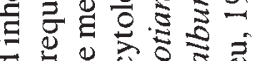

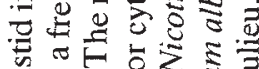

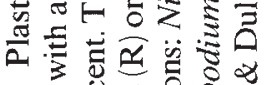

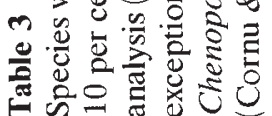

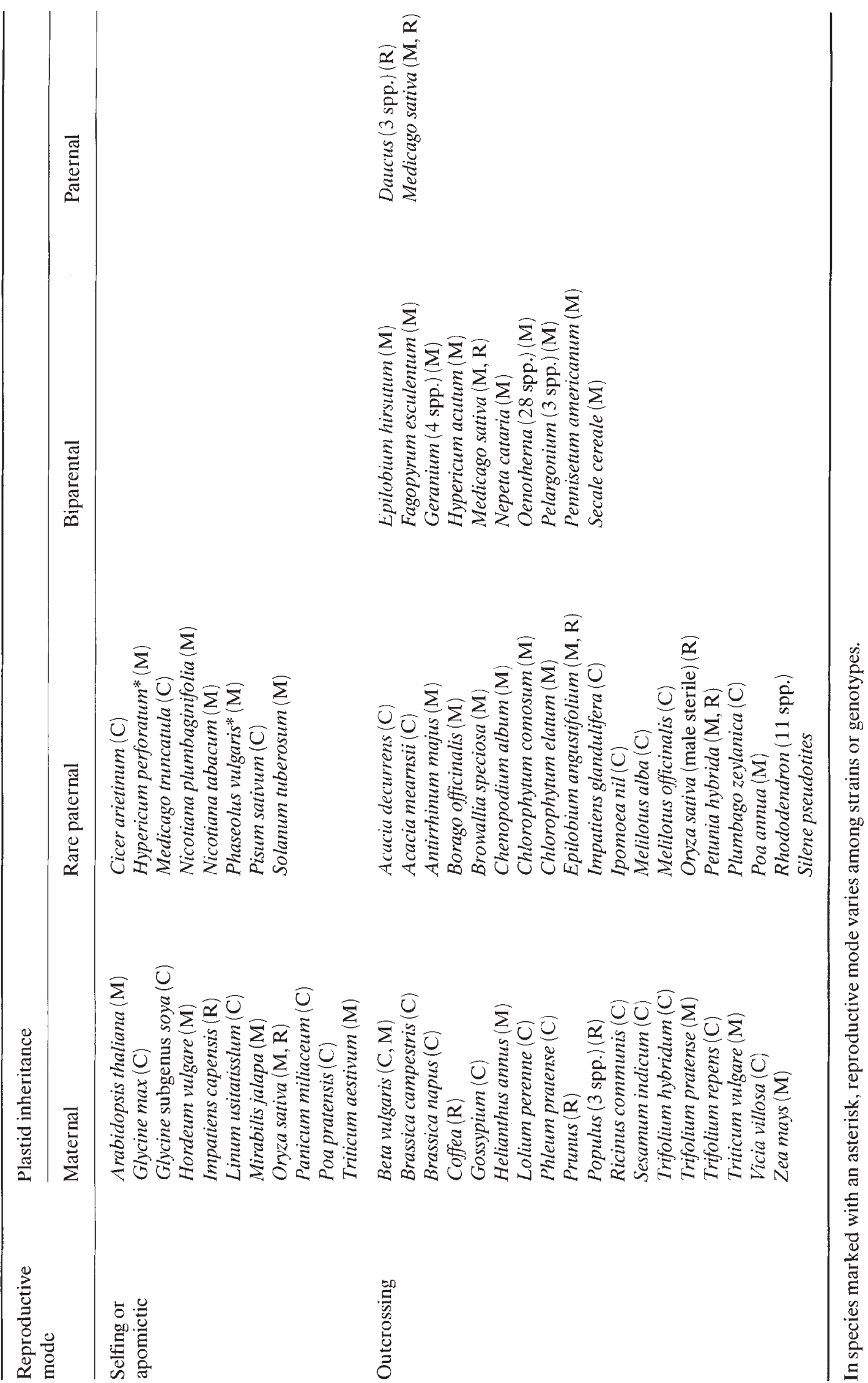


3 Probably because of the difficulty of obtaining seeds from crosses, selfing species are also underrepresented. This bias towards outcrossers may have distorted our view of the genetic systems controlling organelle inheritance, as the potential for both conflict and cooperation between organelles and nuclear genomes is radically modified by changes in the reproductive system (Cosmides \& Tooby, 1981).

4 The absence in most species of phenotypic markers which would permit extensive sampling, and the low sensitivity of RFLP analysis to small amounts of DNA, have led to underestimates of the frequency of heteroplasmy and rare biparental inheritance. For example, the use of a drug resistance marker showed that rare paternal inheritance of plastids occurs in Nicotiana (Medgyesy et al., 1986), a taxon which was previously thought to have exclusively maternal plastid inheritance (Kirk \& Tilney-Bassett, 1978; Corriveau \& Coleman, 1988). Schmitz \& Kowallik (1986) observed only maternal inheritance in Epilobium using RFLPs, while the use of mutants carrying white plastids revealed a few cases of apparent paternal transmission. Thus, the apparent rarity of heteroplasmy and paternal plastid transmission may be an artefact of technical limitations which should soon be overcome.

\section{Mechanisms of organelle inheritance}

Mechanisms of organelle inheritance have been explored primarily by cytological studies of organelle exclusion during gametogenesis and embryogenesis. Used by Corriveau \& Coleman (1988) to detect rapidly the potential for biparental plastid inheritance, cytological study showed that plastids are absent from the sperm cells of 192 of 235 angiosperm species, where more or less strictly maternal inheritance is thus expected, and is usually observed.

A major cytological observation has been the polarization of generative cells prior to mitosis in some species. Russell (1987), looking at sperm cell formation in Plumbago zeylanica, found an unequal distribution of organelles due to premitotic polarization of generative cells. The sperm associated with the vegetative nucleus has a long cellular projection which lies within embayments of that nucleus and contains the majority of the mitochondria and a few plastids. The second sperm is connected to the first by a large cellular projection and contains significantly fewer mitochondria and numerous plastids. The number of paternal mitochondria transmitted into the central cell, which will become endosperm, is greater than that transmitted into the egg as the result of preferential fertilization (93 per cent) by the mitochondrion-rich dimorphic sperm cell. This results in a paternal to maternal ratio in the egg of $1: 1000$ for mitochondria and $1: 31$ for plastids. To date, cytoplasmic heterospermy has been detected in Plumbago zeylanica (Russell, 1984), Brassica campestris, B. oleracea (McConchie et al., 1987) and Spinacia oleracea (Wilms, 1986), and has been proven to be absent only in Hordeum vulgare (Mogensen \& Rusche, 1985). In general, this germ cell polarization could partly account for differences in the inheritance of chloroplasts compared with mitochondria. It also presents an evolutionary paradox: mitochondria appear to behave suicidally by entering a sperm cell which will never transmit them, although this probably increases the fitness of the embryo. Therefore, in such cases, mitochondrial segregation must be controlled by nuclear genes. Paternally-derived nuclear genes in the embryo may benefit from the presence of paternal mitochondria in the endosperm (if, for example, they increase the allocation of material resources to the embryo) whereas mitochondria with a self-encoded tendency towards transmission by both parents would be expected to outcompete those that exclude themselves from paternal transmission.

All cytological studies of maternal to paternal plastid ratios in the egg have found ratios of $2: 1$ to 31:1 (Richter-Landmann, 1959; Meyer \& Stubbe, 1974; Russell, 1987; Tilney-Bassett \& Almouslem, 1989). Even in Pelargonium cultivars where some families can show frequent paternal transmission, the ratios are never to the advantage of the paternal plastids (Tilney-Bassett \& Almouslem, 1989). This fact could account for the bias toward more maternal than paternal inheritance of plastids in angiosperms. The bias created by anisogamy cannot entirely explain the excess of maternal inheritance, as uniparental 'maternal' inheritance is also found in isogamous species of algae such as Ulva mutabilis (Bråten, 1971) and Chlamydomonas reinhardtii (see review by Sears, 1980). However, cytological analyses have at least clarified mechanisms of organelle exclusion. During gametogenesis, organelle loss results primarily from the formation of cytoplasmic projections that are subsequently discarded from the sperm cell body (Mogensen \& Rusche, 1985; Morgensen, 1988; Schmitz \& Kowallik, 1987).

To explain both plastid exclusion and the apparent rarity of heteroplasmy, Smith (1988) hypothesized that relatively high frequencies of uniparental progeny indicate that the plastids may not be randomly mixed in the zygote. Tilney-Bassett \& Almouslem (1989) proposed that the paternal plastids remain clustered together within their original cytoplasm; sometimes the whole cluster of paternal plastids manages to displace the maternal plastids from the location that is most 
favourably placed to enter the terminal cell (which will contribute to the embryo) ... Uniparental progency may result from the exclusion of one parent's plastids. As only a fraction of the plastids enter the terminal cell, the population is sampled. Thus, the chance of including plastids from both parents will depend on the effective population size, the amount of spatial heterogeneity in the cytoplasm, the sample size and the relative frequencies of the two types of plastid'. Each of these quantities can be determined cytologically. Whatley (1982) summarized the results of cytological studies by concluding that 'several different mechanisms for exclusion of plastids from particular cells, none of which is completely effective on its own, may operate sequentially during both gametogenesis and embryogenesis. There appears to exist a general trend such that the more highly evolved the organism, the more numerous the mechanisms employed and the earlier they first come into operation'.

Plastid transmission by a gamete does not always result in the persistence of those plastids in the embryo. The plastome of one parent may be actively destroyed following gamete fusion, as in the chlorophyte alga Chlamydomonas reinhardtii (see Harris, 1989). Birky (1983) and Tilney-Bassett \& Birky (1981) have suggested that the frequency of heteroplasmy might be reduced, both within and among embryos, by drift in plastid frequencies, resulting from randomness in plastid replication and segregation.

The genetic control of plastid inheritance has been analysed in several taxa which show variation in plastid inheritance patterns. Plastid inheritance is controlled at least to some extent by nuclear genes, which may be either expressed in the maternal lineage, as in Pelargonium (Kirk \& Tilney-Bassett, 1978; Tilney-Bassett, 1988), paternally expressed as in Petunia (Derepas \& Dulieu, 1992), or influenced by both maternal and paternal genotypes, as in Medicago sativa (Smith, cited by Tilney-Bassett \& Almouselm, 1989). In Chlamydomonas reinhardtil, the diploid zygotes inherit and transmit to haploid spores the chloroplasts of the mating type plus parent and the mitochondria of the mating type minus parent (see Bolen et al., 1982; Boynton et al., 1987; Birky et al., 1981; Lee et al., 1990). Plastid transmission can also be affected by the plastid genome (Chiu et al., 1988) and by plastome-genome interactions, as in Oenothera (Chiu \& Sears, 1993).

Uniparental and biparental inheritance clearly are not fixed alternatives. They are often reversible conditions whose frequencies in a population can respond to selection (Schötz, 1975; Derepas \& Dulieu, 1992; Tilney-Bassett \& Almouslem, 1989).

\section{Evolutionary reasons for variability in plastid inheritance}

In her review on the ultrastructure of plastid inheritance, Whatley (1982) suggests strongly that many of the mechanisms that appear to affect plastid inheritance are incidental by-products of other evolutionary events. Concerning Chlamydomonas and other algae, Coleman (1982) suggested that "elimination of paternal genomes is a manifestation of mechanisms that protect egg cells from infection by foreign organisms, perhaps potential endosymbionts'.

Reasons for uniparental inheritance have been proposed with reference to the advantages and disadvantages of sexual reproduction. In particular, recombination may break up adaptative combinations of alleles. Biparental inheritance also facilitates the spread of genes or genomes that replicate more rapidly than the wild-type but reduce the fitness of the cell. These disadvantages have led some authors (reviewed by Birky, 1983) to suggest that monogametic transmission and selective silencing may have evolved to reduce or prevent recombination among organelles. Uniparental inheritance may prevent invasion by transposons, which seem to be much less abundant in chloroplast genomes than in those of mitochondria or nuclei. Alternatively, the general absence of transposons from chloroplasts may have relaxed selection for uniparental inheritance. In either case, the correlation between transposon abundance and inheritance patterns of genomes may merit examination.

Uniparental inheritance results in clonal reproduction and prevents recombination, a situation which is unusual in biology and contrasts with that of nuclear genomes. In procaryotes, exchange of DNA can be mediated by conjugative plasmids. Cases of higher eukaryotic taxa with strictly clonal reproduction are exceptions to the general rule (Maynard Smith, 1989). However, a mode of organelle reproduction that occurs in nearly all eucaryotic cells cannot be dismissed as an anecdote. It is not obvious why organelle genomes should be the only ones that never recombine. In the absence of recombination, the classes of organelles least burdened by mildly deleterious mutations will sequentially disappear due to sampling error from one generation to the next, a process known as Muller's Ratchet (Muller, 1964). Even rare recombination prevents this phenomenon by regenerating mutation-free genomes. Strictly maternal organelle inheritance should thus be deleterious. In contrast to plastids (Malone et al., 1992), mitochondria seem to recombine frequently (Dujon, 1981; Birky et al., 1982), so perhaps paternal inheritance of mito- 
chondria need not be common to regenerate a 'clean' genome.

Mechanisms of organelle inheritance have received more attention than their evolutionary explanation (e.g. Coleman, 1982; Cosmides \& Tooby, 1981; Hurst \& Hamilton, 1992; Hoekstra, 1990). The usual explanation, that uniparental inheritance prevents intracellular conflict and impedes the spread of selfish elements, although true, is unsatisfactory because, like many explanations of sexual reproduction, it relies on grouplevel or long-term effects. Uniparental inheritance must somehow overcome the invasive potential of organelles which are transmitted by both parents. We know that transposons transpose, that viruses are infectious and that some B-chromosomes can distort segregation ratios (Roman, 1948). Thus it is not obvious to us why organelles should be purely passive concerning their inheritance. The nuclear/cytoplasmic conflict in male sterility (Gouyon \& Couvet, 1988) shows that there exist some opportunities for mitochondrial genomes to modify the reproductive system in their favour. The multiple mechanisms involved in preventing biparental inheritance, none of which is completely effective on its own, suggest the occurrence of a 'Red Queen' process between organelle and nuclear genomes. These multiple mechanisms could be the outcome of continuing efforts by each of the conflicting genomes to overcome the defenses of the other.

Using the species listed in Table 3, we test the proposition that plastids could influence their modes of inheritance. Two hypotheses give rise to opposite expectations. (i) Under the hypothesis that only the nuclear genome is responsible for organelle inheritance, selection for such control should be relaxed in selfing angiosperms, where potential conflict between organelles of different origins is far less frequent. With self-fertilization, the plastids present in the sperm cell are the same as those in the female gamete, so mutations which relax nuclear control of plastid inheritance are neutral. Thus biparental inheritance should be more common in selfing than outcrossing species. (ii) If plastids can drive their inheritance, a biparentally inherited plastid will invade an outcrossing population, while in selfing species such plastids would only replace other copies of themselves. Thus, biparental inheritance, or at least pollen bearing plastids, should be more common in outcrossing than in selfing species.

Although it is difficult to categorize the reproductive system in many species, we sorted according to their reproductive systems the angiosperm species for which this was possible (Table 3). Because both the phylogeny and reproductive systems are known for very few species, a more rigorous test using comparative methods was not possible. Maternal and rare paternal inheritance are found in many species of both reproductive modes. By contrast, we found no data indicating a greater than 10 per cent frequency of paternal chloroplast transmission in any apomictic or selfing plants, although there are numerous cases in outcrossing species. A possible exception is Hypericum perforatum, which Fryxell (1957) described as apomictic. Taking the Graminae as an example, biparental inheritance is found in Pennisetum americanum (Krishna Rao \& Koduru, 1978) and Secale cereale (Karas \& Cass, 1976), two species known to have an allogamous reproductive system, whereas no paternal transmission of plastids has been detected in Triticum aestivum (Hagemann \& Schroder, 1989) and Hordeum vulgare (Mogensen, 1988). In Oryza, a potential paternal inheritance is found in a male sterile line, which thus differs radically in its reproductive system from other Oryza lines (Dally \& Second, 1990). In all cases in which congeneric species have differing reproductive modes (Poa, Impatiens and Medicago), biparental plastid inheritance is more common in the outcrossing species. Moreover, paternal or biparental inheritance is found in all gymnosperms which are known to be outcrossers (Table 4). These data support the proposition that plastids can influence their inheritance. However, some major qualifications should be noted: the difficulty of obtaining numerous intercrossing progeny in preferentially selfing species reduces the probability of observing paternal transmission, producing a bias towards observing more biparental inheritance in outcrossers. As discussed above, the species whose plastid inheritance has been studied is also a biased sample, as many are species of agronomic interest, in which artificial selection may have considerably modified the reproductive system and nuclear-cytoplasmic interactions. This survey also lacks purely outbreeding angiosperms (self-incompatible, dioecious species).

Despite the exceptions noted, we may still wonder why biparental inheritance is relatively rare. One explanation could be that plastid mutants capable of more efficient paternal transmission also face a tradeoff that decreases their maternal transmission. Plastids which are specialized for the female gamete (or male, in the case of Daucus (Boblenz et al., 1990)) may be fitter than organelles transmitted in the differing cellular environments of both male and female gametes. Investigation of this possibility would require a molecular ecological approach: does adaption to the cellular environment of one gamete type come at the expense of adaption to transmission by the other gamete?

\section{Conclusion}

A literature survey shows that organelle inheritance is controlled in different ways in different taxa. A particu- 
Table 4 Gymnosperms with plastid inheritance other than strictly maternal with methods of analysis abbreviated as in Table 3

\begin{tabular}{lll}
\hline Species & $\begin{array}{l}\text { Plastid } \\
\text { inheritance }\end{array}$ & Reference \\
\hline Biota orientalis & $\mathrm{P}$ & Chesnoy $(1969)$ \\
Calocedrus decurrens & $\mathrm{P}$ & Neale et al. $(1991)$ \\
Cryptomeria japonica & $\mathrm{P}$ & Ohba et al. $(1971) ;(\mathrm{M})$ \\
Larix decidua & $\mathrm{B}$ & Szmidt et al. $(1987) ;(\mathrm{R})$ \\
Larix leptolepis & $\mathrm{B}$ & Szmidt et al. $(1988) ;(\mathrm{R})$ \\
Picea pungens & $\mathrm{P}$ & Stine et al. $(1989) ;(\mathrm{R})$ \\
Picea glauca & $\mathrm{P}$ & Stine et al. $(1989) ;(\mathrm{R})$ \\
Pinus contorta $\times$ banksiana & $\mathrm{P}$ & Wagner et al. $(1987) ;(\mathrm{R})$ \\
Pinus taeda & $\mathrm{P}$ & Neale et al. $(1989) ;(\mathrm{R})$ \\
Pseudotsuga menziesii & $\mathrm{P}$ & Neale et al. $(1986) ;(\mathrm{R})$ \\
Sequoia sempervirens & $\mathrm{P}$ & Neale \& Sederoff $(1989) ;$ \\
& & $(\mathrm{R})$ \\
\hline
\end{tabular}

P: paternal; B: at least some biparental.

lar pattern of organelle inheritance may reflect the efficiency or lack of efficiency of these combined mechanisms. We argue that these patterns are not merely by-products of other evolutionary processes but are directly acted on by selection. Major apparent differences between the transmission patterns of chloroplasts and mitochondria remain to be explained, perhaps with reference to other differences such as the occurrence of transposons and recombination. Although uniparental inheritance prevents conflict between organelles of different origins and impedes the spread of selfish elements, these are not short-term effects and thus do not suffice to explain why mutant organelles with more efficient biparental transmission have not been successful. Evidence that such mutations impose some cost on organelle replication or maternal transmission could provide an explanation.

\section{Acknowledgements}

This work was supported by INRA and the French Ministry of Research and Technology. We thank B. Godelle, D. Schoen and an anonymous reviewer for helpful comments on the manuscript.

\section{References}

BIRKY, C. W. Jr. 1983. Relaxed cellular controls and organelle heredity. Science, 222, 468-475.

BIRKY, C. W., Jr., ACTON, A. R., DIETRICH, R. AND CARVER, M. 1982. Mitochondrial transmission genetics: replication, recombination and segregation of mitochondrial DNA and its inheritance in crosses. In: Slonimski, P., Borst, P. and
Attardi, G. (eds) Mitochondrial Genes, pp. 333-348. Cold Spring Harbor Laboratory, New York.

BIRKY, C. W., Jr., VAN WINKLE-SWIFT, K. P., SEARS, B. B., BOYNTON, J. E. AND GILlHaM, N. w. 1981. Frequency distribution of chloroplast genes in Chlamydomonas zygote clones: evidence for random drift. Plasmid, 6, 173-192.

BoblenZ, K., NOThNaGel, T. AND METZlafF, M. 1990. Paternal inheritance of plastids in the genus Daucus. Mol. Gen. Genet., 220, 489-491.

BOLEN, P. L., GRANT, D. M., SWINTON, D., BOYNTON, J. E. AND GILLHAM, N. w. 1982. Extensive methylation of chloroplast DNA by a nuclear gene mutation does not affect chloroplast gene transmission in Chlamydomonas. Cell, 28, 335-343.

BOYNTON, J. E., HARRIS, E. H., BURKHART, B. D., LAMERSON, P. M. AND GILlham, N. W. 1987. Transmission of mitochondrial and chloroplast genomes in crosses of Chlamydomonas. Proc. Natl. Acad. Sci. USA, 84, 2391-2395.

BRATEN, T. 1971. The ultrastructure of fertilization and zygote formation in the green alga Ulva mutabilis. J. Cell. Sci., 12 , $385-389$.

CHESNOY, L. 1969. Sur la participation due gamete male a la constitution du cytoplasme de le'embryon chez le Biota orientalis. Rev. Cytol. Biol. Veg., 32, 273-294.

CHIU, w. L. AND SEARS, B. B. 1993. Plastome-genome interactions affect plastid transmission in Oenothera. Genetics, 133, 989-997.

CHIU, w. L., STUBBE, w. AND SEARS B. B. 1988. Plastid inheritance in Oenothera: organelle genome determines the extent of biparental plastid transmission. Curr. Genet., 13, 181-189.

COLEMAN, A. w. 1982. Sex is dangerous in a world of potential symbionts or the basis of selection for uniparental inheritance. J. Theor. Biol., 97, 367-369.

CORNU, A. AND DULIEU, H. 1988. Pollen transmission of plastid DNA under genotypic control in Petunia hybrida Hort. $J$. Hered., 79, 40-44. 
CORRENS, C. 1909. Verebungsversuche mit blass(gelb)grunen und buntblattrigen Siippen bei Mirabilis jalapa, Urtica dioica, Urtica pilulifera und Lunaria annua. Zschr. Induky. Abstamm. Vereb. Lehre., 1, 291-329.

CORRIVEAU, J. L. AND COLEMAN, A. W. 1988. Rapid screening method to detect potential biparental inheritance of plastid DNA and results over 200 angiosperm species. Am. J. Bot., 75, 1443-1458.

COSMIDES, L. D. AND TOOBY, J. 1981. Cytoplasmic inheritance and intragenomic conflict. J. Theor. Biol., 89, 83-129.

DALLY, A. M. AND SECOND, G. 1990. Chloroplast DNA diversity in wild and cultivated species of rice (Genus Oryza, section Oryza). Cladistic-mutation and genetic-distance analysis. Theor. Appl. Genet., 80, 209-222.

DARMENCY, H. AND GASQUEZ, J. 1981. Inheritance of triazine resistance in Poa annua: consequences for population dynamics. New Phytol., 89, 487-493.

DEREPAS, A. 1991. Contrôle génétique de la transmission des plastes d'origine paternelle chez Petunia hybrida Hort. Thèse de l'Université de Bourgogne.

DEREPAS, A. AND DULIEU, H. 1992. Inheritance of the capacity to transfer plastids by the pollen parent in Petunia hybrida Hort.. J. Hered., 83, 6-10.

DERKS, F. H. M., HAKKERT, J. C., VERBEEK, W. H. J. AND COLUNHOOYMANS, C. M. 1992. Genome composition of asymmetric hybrids in relation to the phylogenetic distance between the parents. Nucleus-chloroplast interaction. Theor. Appl. Genet., 84, 930-940.

DUJON, B. 1981. Mitochondrial genetics and functions. In: Strathern, J. N., Jones, E. W. and Broach, J. R. (eds) The Molecular Biology of Yeast Saccharomyces, vol. 1, pp. 505-635. Cold Spring Harbor Laboratory, New York.

ERICKSON, L., KEMBLE, R. AND SWANSON, E. 1989. The Brassica mitochondrial plasmid can be sexually transmitted. Pollen transfer of a cytoplasmic genetic element. Mol. Gen. Genet., 218, 419-422.

FRYXELL, P. A. 1957. Mode of reproduction of higher plants. Bot. Rev., 23, 135-233.

GASQUEZ, J., DARMENCY, H. AND COMPOINT, J. P. 1981. Etude de la transmission de la résistance chloroplastique aux triazines chez Solanum nigrum. C. R. Acad. Sa. Paris, 292, 847-849.

GASQUeZ, J., El MOUEMAR, A. AND DARMENCY, H. 1985. Triazine herbicide resistance in Chenopodium album L. : occurrence and characteristics of intermediate biotype. Pest. Sci., 16, 390-395.

GOUYON, P. H. AND COUVET, D. 1988. A conflict amongst the sexes, females and hermaphrodites. In: Stearns, S. C. (ed.) The Evolution of Sex and its Consequences, Birkhauser Verlag.

HAGEMANN, R. AND SCHRODER, M. B.1985. New results about the presence of plastids in generative and sperm cells of Gramineae. In: Sexual Reproduction in Seed Plants Ferms and Mosses. pp. 53-55. PUDOC, Wageningen.

HAGEMANN, R. AND SCHRODER, M. B. 1989. The cytological basis of the plastid inheritance in angiosperms. Protoplasma, 152, 57-64.

HARRIS, E. 1989. The Chlamydomonas Source Book. Academic Press, New York.
HOEKSTRA, R. F. 1990. Evolution of uniparental inheritance of cytoplasmic DNA. In: Maynard-Smith, J. and Vida, G. (eds) Organisational Constraints on the Dynamics of Evolution, pp. 269-278. Manchester University Press, Manchester.

HURST, L. D. AND HAMILTON, w. D. 1982. Cytoplasmic fusion and the nature of sexes. Proc. R. Soc. Lond. B, 247, 189-194.

KANEKO, T., TERACHI, T. AND TESUNEWAKI, K. 1986. Studies on the origin of crop species by restriction endonuclease analysis of organellear DNA. II. Restriction analysis of ctDNA of 11 Prunus species. Jpn. J. Genet., 61, 157-168.

KARAS, I. AND CASS, D. D. 1976. Ultrastructural aspects of sperm cell formation in rye: evidence for cell plate involvement in generative cell division. Phytomorphology, 26, 36-45.

KIRK, J. T. O. AND TILNEY-BASSETT, R. A. E. 1978. The Plastids: Their Chemistry, Structure, Growth and Inheritance, revised 2nd edn. Elsevier/North-Holland Biomedical press, Amsterdam/New York/Oxford.

KRISHNA RAO, M, AND KODURU, P. R. K. 1978. Biparental plastid inheritance in Pennisetum americanum. J. Hered., 69 , 327-330.

LEE, R. W., LANGILLE, B., LEMIEUX, C. AND BOER, P. H. 1990. Inheritance of mitochondrial and chloroplast genome markers in backcrosses of Chlamydomonas eugametos $\times$ Chlamydomonas moewusii hybrids. Curr. Genet., 17, 73-76.

MALONE, R., HORVATH, G. V., CSEPLO, A., BUZAS, B., DIX, P. J. AND MEDGYESY, P. 1992. Impact of the stringency of cell selection on plastid segregation in protoplast fusion-derived Nicotiana regenerates. Theor. Appl. Genet., 84, 866-873.

MAYNARD SMITH, J. 1989. Evolutionary Genetics. Oxford University Press, Oxford, p. 239.

McCONCHIE, C. A., RUSSELl, S. D., DUMAS, C., TUOHY, M. AND KNOW, R. B. 1987. Quantitative cytology of the sperm cells of Brassica campestris and B. oleracea. Planta, 170, 446-452.

MEDGYESY, P., PAY, A. AND MARTON, L. 1986. Transmission of paternal chloroplasts in Nicotiana. Mol. Gen. Genet., 204, 195-198.

MEJNARTOWICZ, M. 1991. Inheritance of chloroplast DNA in Populus. Theor. Appl. Genet., 82, 477-480.

MEYER, R. AND STUBBE, w. 1974. Das Zahlenverhältenis von mütterlichen und väterlichen Plastiden in den Zygoten von Oenothera erythrosepala Borbas. Ber. Deutch. Bot. Ges., 87, 29-38.

MOGENSEN, H. L. 1988. Exclusion of male mitochondria and plastids during syngamy as a basis for maternal inheritance. Proc. Nat. Acad. Sci. USA, 85, 2594-2597.

MOGENSEN, H. L., RUSCHE, M. L. 9185. Quantitative ultrastructural analysis of barley sperm. I. Occurrence and mechanism of cytoplasm and organelle reduction and the question of sperm dimorphism. Protoplasma, 128, 1-13.

MULLER, H. J. 1964. The relation of recombination to mutational advance. Mutat. Res., 43, 165-229.

NEALE, D. B., MARSHALL, K. A. AND HARRY, D. E. 1991. Inheritance of chloroplast and mitochondrial DNA in incense-cedar (Calocedrus decurrens). Can. J. For. Res., 21, 717-720.

NEALE, D. B., MARSHALL, K. A. AND SEDEROFF, R. R. 1989. Chloroplast and mitochondrial DNA are paternally inherited in 
Sequoia sempervirens D. Don Endl. Proc. Natl. Acad. Sci. USA., 86, 9347-9349.

NEALE, D. B. AND SEDEROFF, R. R. 1989. Paternal inheritance of chloroplast DNA and maternal inheritance of mitochondrial DNA in loblolly pine. Theor. Appl. Gent., 77, 212-216.

NEALE, D. B., WHEElER, N. C. AND Allard, R. W. 1986. Paternal inheritance of chloroplast DNA in Douglas fir. Can. J. For. Res., 16, 1152-1154.

OHBA, K., IWAKAWA, M., OKADA, Y. AND MURAI, M. 1971. Paternal transmission of a plastid anomaly in some reciprocal crosses of Sugi, Cryptomeria japonica D. Don. Silvae Genet., 20, 101-107.

R1CHTER-LANDMANN, w. 1959. Der Befruchtungsvorgant bei Impatiens glandulifera Royle unter Berücksichtigung der plasmatischen Organelle von Spermzelle, Eizelle und Zygote. Planta, 53, 162-177.

Roman, H. 1948. Directed fertilization in maize. Proc. Nat. Acad. Sci. USA, 34, 46-52.

RUSSELL, S. D. 1984. Ultrastructure of the sperm of Plumbago zeylanica. 2. Quantitative cytology and three-dimensional reconstitution. Planta, 162, 385-391.

RUSSELL, S. D. 1987. Quantitative cytology of the egg and central cell of Plumbago zelanica and its impact on the cytoplasmic inheritance patterns. Theor. Appl. Genet., 74, 693-699.

SCHEMSKE, D. W. AND LANDE, R. 1985. The evolution of selffertilization and inbreeding depression in plants. 11. Empirical observations. Evolution, 39, 41-52.

SCHMITZ, U. K. AND KOWALLIK, K. v. 1986. Plastid inheritance in Epilobium. Curr. Gent., 11, 1-5.

SCHMITZ, U. K. AND KoWALLIK, K. v. 1987. Why are plastids maternally inherited in Epilobrium? Plant Sci., 53, $139-145$.

SCHÖTZ, F. 1975. Untersuchungen uber die plastidenkonkurenz bie Oenothera, V. Biol. Zbl., 94, 17-26.

SEARS, B. B. 1980. Elimination of plastids during Spermatogenesis and fertilization in the plant kingdom. Plasmid, 4, 233-255.

Simmonds, N. W. 1976. Evolution of Crop Plants. Longman, New York.

SMITH, S. E. 1988. Biparental inheritance of organelles and its implications in crop improvement. Plant Breed. Rev., 6 , 361-393.
SOLIMAN, K., FEDAK, G. AND ALLARD, R. W. 1987. Inheritance of organelle DNA in barley and Hordeum $\times$ Secale intergeneric hybrids. Genome, 29, 867-872.

STINE, M., SEARS, B. B. AND KEATHLEY, D. E. 1989. Inheritance of plastids in interspecific hybrids of blue spruce and white spruce. Theor. Appl. Genet., 78, 768-774.

SUNBERG, E. AND GLIMELIUS, K. 1991. Effects of parental ploidy level and genetic divergence on chromosome elimination and chloroplast segregation in somatic hybrids within Brassicaceae. Theor. Appl. Genet., 83, 81-88.

SZMIDT, A. E., ALDEN, T. AND HÄLlgREN, J. E. 1987. Paternal inheritance of chloroplast DNA in Larix. Plant Mol. Biol., 9, 59-64.

SZMIDT, A. E., El KASSABy, Y. A., SIGURGEIRSSON, A. ALDEN, T., LINDGREN, D. AND HÄLlGREN, J. E. 1988. Classifying seedlots of Picea sitchensis and P. Glauca in zones of introgression using restriction analysis of chloroplast DNA. Theor. Appl. Genet., 76, 841-845.

TILNEY-BASSETT, R. A. E. 1988. Inheritance of plastids in Pelargonium. In: Boffey, S. A. and Lloyd, D. (eds) The Division and Segregation of Organelles, Society for Experimental Biology Seminar series 35, pp. 115-129. Cambridge University Press, Cambridge.

TILNEY-BASSETT, R. A. E. AND ALMOUSLEM, A. B. 1989. Variation in plastid inheritance between Perlargonium cultivars and their hybrids. Heredity, 63, 145-153.

TILNEY-BASSETT, R. A. E. AND BIRKY C. W. 1981. The mechanism of the mixed inheritance of chloroplast genes in Pelargonium. Theor. Appl. Genet., 60, 43-53.

WAGNER, D. B., DONG, J., CARLSON, M. R. AND YANCHUK, A. D. 1991. Paternal leakage of mitochondrial DNA in Pinus. Theor. Appl. Genet., 82, 510-514.

WAGNER, D. B., FURNIER, G. R., SAGHAI-MAROOF, M. A., WILLIAMS, S. M., DANCIK, B. P. AND Allard, R. W. 1987. Chloroplast DNA polymorphisms in lodgepole and jack pines and their hybrids. Proc. Natl. Acad. Sci. USA , 84, 2097-2100.

WHATLEY, J. M. 1982. Ultrastructure of plastid inheritance: green algae to angiosperms. Biol. Rev., 57, 527-569.

wILMS, H. J. 1986. Dimorphic sperm cells in the pollen grain of Spinacia. In: Cresti, M. and Dallai, R. (eds) Biology of Reproduction and Cell Mobility in Plants and Animals, pp. 193-198. University of Siena, Siena, Italy. 